\title{
Soil Quality of a Rice Organic Farm in Langkong, M'lang, Cotabato
}

\author{
Kathleen C. Cedeño ${ }^{1}$
}

\begin{abstract}
Soil quality is crucial to global food production security. However, research data on soil quality, which is vital to enhancing soil fertility and crop yield, is limited particularly on the soil in the rice fields located in Langkong, Mlang, Cotabato. This study aims to assess the soil quality of one of the organic rice farms in said area. Soil samples were collected in thirty-one (31) paddies for two sampling periods: thirty (30) days after harvest and thirty (30) days after rice transplanting. Eight (8) soil indicators representing soil physicochemical characteristics were measured from o-15 $\mathrm{cm}$ depth; the indicators were soil texture, water holding capacity, $\mathrm{pH}$, exchangeable phosphorus, extractable potassium, total organic matter, electrical conductivity, and cation exchange capacity. Results reveal that soils in the studied area are characterized by clay loam with moderate water-holding capacity of about $62.57 \%$ and $60.57 \%$ for both sampling periods, respectively. The soil is strongly acidic (5.3 and 5.5) and has a low amount of organic matter (2.16\% and $1.57 \%)$ and exchangeable P (8.55 ppm and 2.48
\end{abstract}

Kathleen C. Cedeño is faculty of the College of Arts and Sciences.

She can be reached at k.cedeno@usep.edu.ph.

The author is grateful to the College of Arts and Sciences and the Research and Extension Divisions of the University of Southeastern Philippines for funding this study. Special thanks to Don Bosco Multipurpose Cooperative and the owner of the organic rice farm for the constant support extended particularly during the sampling periods. 
ppm), although it has marginal extractable K (80.77 ppm and $91.10 \mathrm{ppm})$. Also, the soils are non-saline and have low cation exchange capacity. The findings signify that the soils have insufficient fertility to sustain the optimal growth of the rice plants which can potentially reduce the yield of rice production. Thus, amendment of the soil quality and enhancement of soil management practices should be taken into consideration to further improve soil fertility to ensure productivity and profitability of farmers.

Keywords: Soil quality, organic rice farm, M'Lang Cotabato

The Philippines had approximately 4.7 million hectares of rice lands and produced about 11.2 million metric tons of milled rice in 2013 (International Rice Research Institute, 2015). In 2014, the rice production growth of the country exceeded the previous year's record by $2.87 \%$ or 528,406 million tons. This increase is attributed to the $3 \%$ improvement in the average yield per hectare (IRRI, 2015). Although the country is one of the leading producers of rice in the world, it still could not fulfil the rice demands of its rapidly growing population (Apun et al., 2014).

Maintenance and sustainability of high crop production yield are credited to several factors, such as the quality of irrigation water, climate, soil, and variety of hybrid rice seeds. Among these factors, soil quality is considered the primary indicator for measuring the sustainability of agricultural system (Surekha et al., 2010). Soil quality is described as the ability of the soil to perform ecological services within natural or managed ecosystem unit limits to support plant and animal yield, preserve or enrich air and water quality, and maintain the health of society (Karlen et al., 1997). Soil quality like other soil properties could 
vary spatially. Several studies have documented that the spatial variability of soil physical properties among and within agricultural fields are inherent in nature due to geologic formation (Gulser et al., 2016) and agricultural management practices (Fazle Rabbi et al., 2014; Gałka et al., 2016) causing spatial variability in crop yields (Usowicz \& Lipiec, 2017).

Soil quality is commonly assessed based on its physical, chemical and biological properties. Soil acidity (soil $\mathrm{pH}$ ), salinity, cation exchange capacity (CEC), soil texture, soil organic matter, and total nitrogen are some of the essential indicators to assess soil quality for sustainable agricultural production. Soil $\mathrm{pH}$ reveals the general picture of the medium for plant growth including nutrient supply trend, the fate of added nutrients, salinity status, soil aeration, soil mineralogy, and weather conditions of the area. Most crops develop best in soil with $\mathrm{pH}$ from 5.5 to 6.5 (Pham et al., 2018). Salinity affects plant growth by decreasing water absorption of plant and uptake of nutrients. Plants under extreme salinity conditions may be damaged causing the plants to sag. Cation exchange capacity (CEC), on the other hand, measures water retention capacity. It influences soil structure stability, nutrient availability, soil $\mathrm{pH}$, and the soil's reaction to fertilizers (Hazleton \& Murphy, 2007). Soil texture affects the retention of nutrient and water in soil (Owji et al., 2014).

The chemical properties of soil influence soil quality by the concentration of nutrients in the soil. Organic matter is considered a vital parameter of soil productivity. It provides nutrients to the land, improves its water-holding capacity, and helps the soil maintain good tilt, thereby providing better aeration for germinating seeds and plant root development (Oldfield et al., 2017). Soil organic matter encourages granulation, increases cation exchange capacity (CEC), and is 
responsible for the absorbing power of the soils up to $90 \%$ (Sarwar et al., 2008). Phosphorus, nitrogen, and potassium are the primary elements for plant growth. Their availability in the soil is controlled by soil $\mathrm{pH}$, clay content, calcareousness, and organic matter percentage of the soil. The ideal $\mathrm{pH}$ for maximum availability of phosphorus ranges from 6.5 to 7.5 (Sarwar et al., 2008).

The continuous use of synthetic fertilizers and agrochemicals degrades soil quality and fertility. The Philippine government supports organic agriculture with the passing of Republic Act 10068, otherwise known as the Organic Agriculture Act of 2010. The act recognizes the urgency of shifting from conventional farming to a sustainable ecological and organic and ecological agriculture model to increase rice productivity, boost farmers' income, promote health for farmers and consumers, and improve soil fertility by arresting the degradation of the environment. Also, several non-profit organizations are encouraging small farmers to shift from their current conventional methods to organic farming (Arandela, 2017). Organic farming relies on crop rotations and the use of crop residues, animal manures, legumes, green manures and organic farm wastes as natural fertilizer sources for crop production and maintenance of soil quality (Choi et al., 2004; Jivraj \& Savaliya, 2004; Thuithaisong et al., 2011). It safeguards soil fertility, improves soil quality and provides farmers with socio-economic benefits compared to conventional farming. Soil quality improvement could be assessed by changes in soil indicators (Reynolds et al., 2007).

Various studies evaluated the physical and chemical characteristics of soil influenced by different organic farming practices in Asia. However, in the Philippines, particularly in Central Mindanao, information about the soil quality of organic rice fields is limited. In this study, soil physicochemical characteristics were evaluated through soil quality 
indicators such as soil texture, water-holding capacity, $\mathrm{pH}$, total organic matter, exchangeable phosphorus, extractable potassium, total organic matter, electrical conductivity, and cation exchange capacity in organic rice files in Langkong, M'lang Cotabato. Soil quality indicators denote measurable soil attributes that influence the capacity of a soil to perform crop production or environmental functions.

\section{Methodology}

\section{Study site}

The study was conducted at Manang Fe's organic rice field located in Langkong, M'lang Cotabato. The rice field consists of 31 paddies (Figure 1). This organic rice farm has been certified by the European Union and awarded with Certification of Environmental Standards (CERES). It has been likewise been granted a certificate by the U.S. Department of Agriculture (USDA) signifying that the organic rice produced in the farm is qualified for export to Europe and the USA. Furthermore, the farm has been supported by the Don Bosco MultiPurpose Cooperative, a non-government organization that helps farmers who adapt and maintain organic farming in Brgy. Langkong.

\section{Soil sampling and analysis}

The thirty-one (31) paddies were labelled from $\mathrm{A}$ to $\mathrm{Z}$ and 1 to 6 (Figure 2). Soil sampling was conducted twice: thirty (30) days after harvest and thirty (30) days after transplanting. The first soil sampling (after harvest) was performed on November 23, 2016, while the second sampling (after transplanting) was on March 1, 2017. For each sampling period, a minimum of five (5) and maximum of ten (10) random soil samples about two (2) to five (5) kilograms were collected per paddy, 


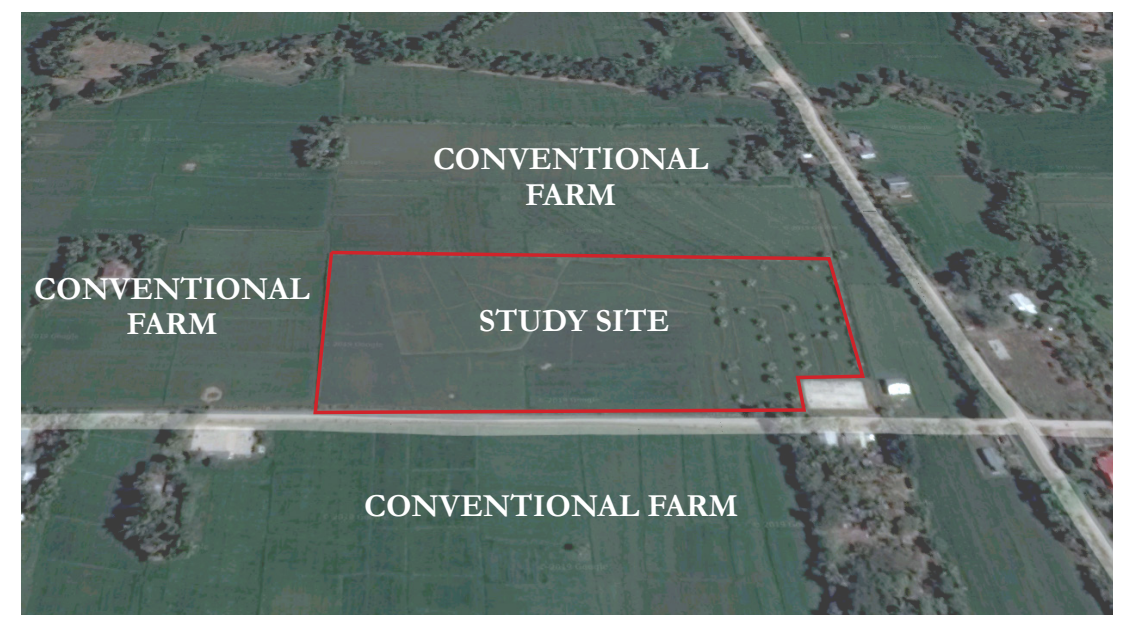

Figure 1. Google Earth view of Manang Fe's organic rice field at Langkong, M'lang Cotabato (red box).

depending on the size of the paddy, at a depth of $0-15 \mathrm{~cm}$ with the use of a bucket auger. Collected representative soil samples per paddy were pooled to obtain composite samples.

These composite soil samples were air-dried at room temperature for 72 hours, and all visible pieces of crop residues and roots were also removed manually. The air-dried soil samples were temporarily conserved in sealed plastic containers and transported to the Department of Agriculture Regional Soils Laboratory, Region XI, Davao City for physicochemical analysis. The sampling method used in this study was adapted from the studies of Ilagan et al. (2014), Lin-lin et al. (2015), Wang et al. (2018), and from the recommended procedures of the DA Regional Soils Laboratory Region XI. Results of soil physicochemical analysis were compared with related literature. 


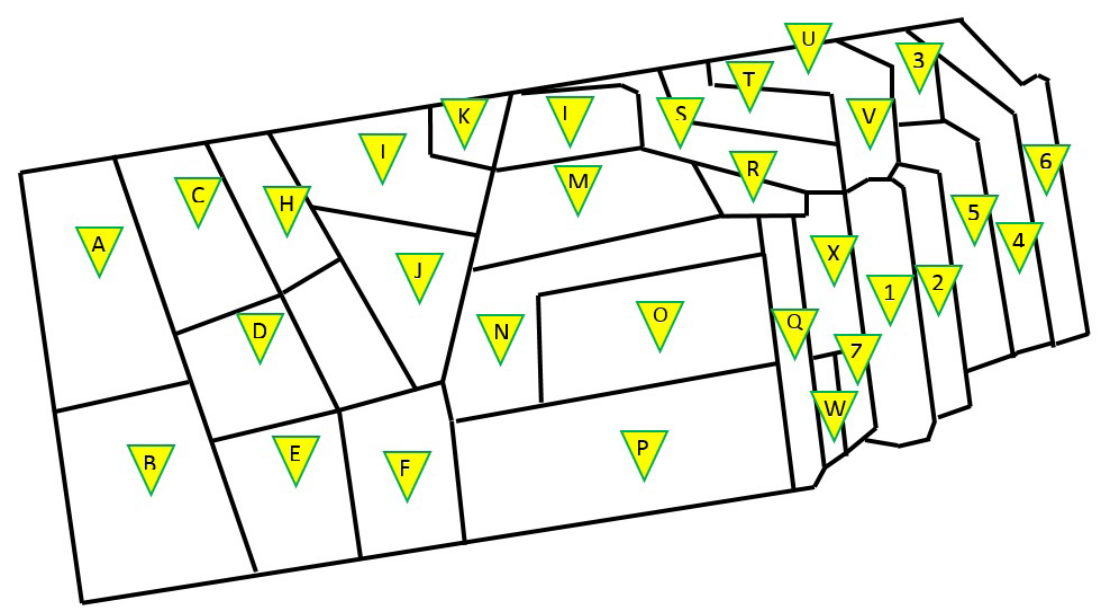

Figure 2. Location of sampling sites as indicated by letters $A$ to $Z$ and numbers 1 to 6

\section{Results and Discussion}

Eight (8) soil quality indicators were measured for the thirty-one (31) composite soil samples. Soil texture and water-holding capacity were recorded and analysed for physical parameters. Chemical indicators like $\mathrm{pH}$, exchangeable phosphorus, extractable potassium, total organic matter, electrical conductivity, and cation exchange capacity were also measured. Table 1 displays the average of the mean and the range values of eight (8) soil quality indicators of the 31 paddies covering the 2 sampling periods. Also included in the table are the threshold value(s) per indicator as presented in the literature. 
Table 1: Soil quality parameters' average mean and range for 31 rice paddies covering two sampling periods; and the parameters' threshold value(s) for rice plant.

\begin{tabular}{|c|c|c|c|c|c|c|c|}
\hline Physical & Unit & After $\mathrm{H}_{2}$ & vest & After Trans & planting & Threshold & Reference \\
\hline & & Average & Range & Average & Range & & \\
\hline Texture & & Clay Loam & & $\begin{array}{l}\text { Clay } \\
\text { Loam }\end{array}$ & & $30-35 \%$ clay & $\begin{array}{l}\text { Hazelton } \\
\& \text { Mur- } \\
\text { phy, } 2007\end{array}$ \\
\hline Sand & $\%$ & 33.4 & $23.2-39.2$ & 33.1 & $22.6-44.6$ & \# & \\
\hline Silt & $\%$ & 31.9 & $29.4-37.4$ & 30.1 & $20.6-44.0$ & \# & \\
\hline Clay & $\%$ & 34.6 & $29.4-41.4$ & 36.5 & $33.4-47.4$ & \# & \\
\hline $\begin{array}{l}\text { Water holding } \\
\text { capacity }\end{array}$ & $\%$ & 62.57 & $50.29-68.86$ & 60.75 & $\begin{array}{l}54.58- \\
67.11\end{array}$ & \# & \\
\hline
\end{tabular}

\begin{tabular}{|c|c|c|c|c|c|c|c|}
\hline $\begin{array}{l}\text { hemical } \\
\text { Indicators }\end{array}$ & Unit & \multicolumn{2}{|c|}{ After Harvest } & \multicolumn{2}{|c|}{ After Transplanting } & $\begin{array}{l}\text { Threshold } \\
\text { Level }\end{array}$ & Reference \\
\hline $\mathrm{pH}$ & & 5.3 & $4.8-5.8$ & 5.5 & $5.0-6.0$ & 5.0 to 6.5 & $\begin{array}{l}\text { Hazel- } \\
\text { ton \& } \\
\text { Murphy, } \\
2007\end{array}$ \\
\hline $\begin{array}{l}\text { Exchangeable } \\
\text { Phosphorus } \\
\text { (Olen P) }\end{array}$ & ppm & 8.55 & $8.0-9.0$ & 2.48 & $1.0-5.0$ & $\begin{array}{l}<5 \mathrm{ppm} \\
\text { (low) } \\
5-10 \mathrm{ppm} \\
\text { (medium) } \\
>10 \mathrm{ppm} \\
\text { (high) }\end{array}$ & $\begin{array}{l}\text { Ilagan et } \\
\text { al., } 2014\end{array}$ \\
\hline $\begin{array}{l}\text { Extractable } \\
\text { Potassium } \\
\text { (cold } \mathrm{H}_{2} \mathrm{SO}_{4} \\
\text { Method) }\end{array}$ & ppm & 80.71 & $55-123$ & 91.10 & $68-118$ & $\begin{array}{l}20-80 \mathrm{ppm} \\
\text { (low) } \\
82-246 \mathrm{ppm} \\
\text { (high) }\end{array}$ & $\begin{array}{l}\text { William \& } \\
\text { Goldman } \\
\text { Smith, } \\
2001\end{array}$ \\
\hline $\begin{array}{l}\text { Total Organic } \\
\text { Matter }\end{array}$ & $\%$ & 2.16 & $1.02-2.91$ & 1.57 & $0.04-2.87$ & $\begin{array}{l}>3 \% \text { (fa- } \\
\text { vorable) } \\
<3 \% \text { (unfa- } \\
\text { vorable) }\end{array}$ & $\begin{array}{l}\text { Ilagan et } \\
\text { al., } 2014\end{array}$ \\
\hline
\end{tabular}




\begin{tabular}{|c|c|c|c|c|c|c|c|}
\hline $\begin{array}{l}\text { Electrical } \\
\text { conductivity }\end{array}$ & $\mathrm{dS} / \mathrm{m}$ & 0.304 & $\begin{array}{l}0.226- \\
0.435\end{array}$ & 0.317 & $\begin{array}{l}0.052- \\
0.422\end{array}$ & $3.0 \mathrm{dS} / \mathrm{m}$ & $\begin{array}{l}\text { Grattan, } \\
2002\end{array}$ \\
\hline $\begin{array}{l}\text { Cation } \\
\text { Exchange } \\
\text { Capacity }\end{array}$ & $\begin{array}{l}\text { meq/ } \\
100 \mathrm{~g}\end{array}$ & 10.26 & $4.22-15.51$ & 8.45 & $5.46-11.02$ & $\begin{array}{l}6-12 \\
\mathrm{meq} / 100 \mathrm{~g} \\
\text { (low) } \\
12-25 \\
\text { meq/100 g } \\
\text { (moderate) } \\
25-40 \\
\text { meq/100 g } \\
\text { (high) } \\
>40 \text { meq/100 } \\
\text { (very high) }\end{array}$ & $\begin{array}{l}\text { Hazel- } \\
\text { ton \& } \\
\text { Murphy, } \\
2007\end{array}$ \\
\hline
\end{tabular}

Legend: \# means no threshold value

\section{Physical Soil Quality Indicators}

\section{$\underline{\text { Soil texture and soil water-holding capacity }}$}

Soil texture is governed by the size and type of solid particles that make up the soil. Soils made up of smaller particle sizes like clay and silt have larger surface area relative to other soil types. The larger the surface area, the easier it is for the soil to hold onto water, so it has a higher waterholding capacity. Analysis has shown that soil texture was clay loam, characterized by nearly equal parts of sand, silt, and clay as displayed in Table 1. These soils had average soil water holding capacities of about $62.57 \%$ and $60.72 \%$ for after harvest and after transplanting, respectively. These findings indicate that the soil can contain more than fifty percent (50\%) amount of water for crop use. 


\section{Chemical Soil Quality Indicators}

\section{$\underline{\text { Soil } \mathrm{pH} \text { value }}$}

One of the important chemical properties principally attributed to minimal rice yield causing low nutrient return by organic materials is soil pH (Arunrat et al., 2017). McCauley et al. (2017) showed that neutral soil $\mathrm{pH}$ appears to be best for crop growth because of better availability of plant nutrients and accumulation of organic matter. Also, the study of Pham et al. (2018) revealed that most crops develop best in soil with $\mathrm{pH}$ from 5.5 to 6.5 . However, some crop varieties can grow in soils with lower $\mathrm{pH}$ (5.0-5.5) like potatoes (McCauley et al., 2017). Likewise, several varieties of rice plants prefer slightly acidic but can grow well at soil pH of 5.0 to 6.5 (Hazelton \& Murphy, 2007).

In the study area, the mean values of soil $\mathrm{pH}$ thirty days after harvest was 5.3 , and a month after transplanting was 5.5, signifying that the soil was extremely acidic. Although rice can grow in acidic soil, it is still best to amend soil $\mathrm{pH}$ to a nearly neutral condition which is of benefit to the rice crop, because this $\mathrm{pH}$ range appears to favour nutrient uptake. The study of Sahrawat (2005) has revealed that secure and fairly economical methods to modify the soil $\mathrm{pH}$ were through applications of calcium carbonate (agricultural lime) and flooding the rice fields for 3-4 weeks.

\section{Exchangeable phosphorus}

Phosphorus is vital for rice growth and root development, tillering, early flowering, and for synthesis of protein (Panhawar \& Othman, 2011; YosefTabar, 2012). Hence low supply of phosphorus lessened plant height and leaf area development during early growth (Duangjai et al., 2000). Ilagan et al. (2014) categorized the available phosphorus level 
for rice as $<5 \mathrm{ppm}, 5-10 \mathrm{ppm}$ and $>10 \mathrm{ppm}$ inclusive for low, medium and high, respectively. Based on the results the study, the average plant's available phosphorus (P) after harvest was $8.55 \mathrm{ppm}$ and thirty (30) days after the transplanting of seeds, the amount depleted to $2.48 \mathrm{ppm}$, which can be attributed to the phosphorus uptake of the plants. This amount is below the critical value of phosphorus in the soil for rice, as suggested by Lin-lin et al. (2015), which is $3.40 \mathrm{ppm}$. Critical soil phosphorus value refers to the soil fertility level corresponding to maximum yield (Mallarino \& Blackmer, 1992). Simpson et al. (2011) suggested that for greater rice yield, it is crucial to maintain the phosphorus concentration of soil closely to the critical phosphorus value.

Moreover, the availability of soil phosphorus is intensely affected by soil pH. At pH below 6.0, phosphorus becomes firmly joined with aluminium and iron oxides. Above pH 7.0, phosphorus becomes tightly bound with calcium (McCauley et al., 2017) causing phosphorus not readily found in soil solution and thus less available for plant uptake. The beneficial availability of phosphorus in soil is within the pH of 6.8 (Lin-lin et al., 2015).

\section{Extractable potassium}

Potassium is essential to the growth cycle of plants. It regulates water status, maintains proper balance of ions, ensures disease resistance, and supports overall rice plant nutrition (Ilagan et al., 2014). Rice is one of those many plants susceptible to diseases when potassium nutrition is deficient or low, which can cause quality losses caused by physiological effects of inadequate $\mathrm{K}$ nutrition. Available potassium for rice ranges with values 20-80 ppm indicating low available potassium and 82-246 ppm signifying high potassium (Williams \& Goldman Smith, 2001; Ilagan et al., 2014). 
As shown in Table 1, the values of potassium observed in the studied rice field for the two sampling periods (after harvest and after transplanting) showed low and high-level potassium or $80.71 \mathrm{ppm}$ and 91.10 ppm respectively. With the observed sufficient available amount of soil potassium, it can be inferred that the ability of rice plants to resist diseases is potentially high.

\section{$\underline{\text { Total organic matter }}$}

Soil organic matter is equally important to plants as it keeps and supplies nutrients essential to productivity, binds soil particles into aggregates, provides habitat for soil organisms that stimulate nutrient cycling, and improves the water-holding capacity of soil (Oldfield et al., 2017). Generally, most soils contain 2-10 percent organic matter yet in even lesser amounts could still be very important (Bot \& Benites, 2005). Nutrient exchanges among soil, water and organic matter are essential to soil fertility and need to be maintained for sustainable production purposes.

About $2.16 \%$ and $1.57 \%$ organic matter $(\% \mathrm{OM})$ were noted in the soil of the study area as displayed in Table 1. These results imply that the amount of soil organic matter available is insufficient for the growth of rice plants. This low amount of soil organic matter may be attributed to the extreme acidity of the soil. Soil $\mathrm{pH}$ affects nutrient availability because the $\mathrm{H}^{+}$ions take up space on the negative charges along the soil surface displacing nutrients. Hence acidic soil impedes availability of nutrients needed by the plants. 


\section{Electrical conductivity (EC)}

EC has been used primarily as a measure of soil salinity or the quantity of salts in the soil. It influences plant growth through reducing water absorption of plant and uptake of nutrients. The presently published salinity threshold for rice yield, plant and tiller densities are at 3.0 deciSiemens per meter $(\mathrm{dS} / \mathrm{m})$, while above $3.0 \mathrm{dS} / \mathrm{m}$ rice growth is adversely affected particularly at the early seedling stages (Grattan, 2002) hence reducing grain yields. Soils with EC values higher than three ( $>3$ $\mathrm{dS} / \mathrm{m}$ ) measured on their saturated extract are considered saline (USDA, 2011 ), and growth of crops sensitive to salinity is restricted in these soils. Soils on the other hand with an EC value of less than $0.4 \mathrm{dS} / \mathrm{m}$ are believed to be non- saline (Grattan, 2002).

The measured EC values of the soil samples for the two sampling periods were less than $0.4 \mathrm{dS} / \mathrm{m}$ as presented in Table 1 . This low value of the soils' EC is favorable to rice plants because the water absorption and nutrients uptake of rice plants became efficient.

\section{Cation Exchange Capacity (CEC)}

Cation exchange capacity is a primary controlling agent of soil $\mathrm{pH}$, soil structure stability and nutrient availability for plant growth, and is the soil's response to fertilisers and other ameliorants. It is also the soil's ability to keep hold of cations in a manner that make cations accessible to plants. Among the cations available in the soil, potassium, magnesium, and calcium ions are significantly consumed by plants (Ketterings et al., 2007). In the study area, the noted average value of CEC for both sampling periods were $10.26 \mathrm{meq} / 100 \mathrm{~g}$ and $8.45 \mathrm{meq} / 100 \mathrm{~g}$ respectively. This result implies that the soil has a low amount of cation exchange capacity. Soils with this characteristic are more likely to develop scarcities 
in potassium $\left(\mathrm{K}^{+}\right)$, magnesium $\left(\mathrm{Mg}^{2+}\right)$ and other cations (Ketterings et al., 2007) and often low in fertility as well as susceptible to soil acidification (Hazelton \& Murphy, 2007).

\section{Conclusion}

Based on the results, it can be deduced that the soil quality of the studied rice field is still suitable for rice production. However, it is incredibly essential to enhance soil fertility considering that there are soil quality indicators like total organic matter, exchangeable phosphorus, and cation exchange capacity in particular which are below the required amount needed for most favorable growth and production of rice.

\section{Recommendation}

Findings suggested that the current farming practices of rice cultivation and soil management employed in the studied rice fields ought to be revisited for possible enhancement or modification. Addition of organic fertilizer should be considered following the locality-specific recommendations for rice to improve soil quality. Similarly, modifying the soil $\mathrm{pH}$ into near neutral condition through adding agricultural lime is important. 


\section{References}

Apun,M.R.F., Bidaswa, C. \& Kirikkanat,M. (2014). The problem with rice. Retrieved November 5, 2017, from https://www.rappler.com/move$\mathrm{ph} /$ issues/hunger/commentaries/73333-problem-rice-shortagephilippines.

Arandela, J. (2017). The System of Rice Intensification (SRI) in the Philippines to benefit farmers, consumers and biodiversity. Retrieved from https://panorama.solutions/en/solution/rice-intensificationsystem-sri-philippines-benefit-farmers-consumers-and-biodiversity.

Arunrat, N., Pumijum, N., Hatano, R. (2017). Practices sustaining soil organic matter and rice yield in a tropical moon region. Soil Science and Plant Nutrition, 1-14.doi.org/10.1080/00380768.2017.1323546

Bot, A. and Benites, J. (2005). The importance of soil organic matter key to drought-resistant soil and sustained food production. Food and Agriculture Organization of the United Nations. Retrieved from http:// www.fao.org/3/a0100e/a0100e00.htm\#Contents

Choi, D. H., Goh, H. G., Lee, Y. J. (2004). The modern technique for organic rice cultivation in Korea. Paper presented at the Benign Environment and Safe Food, 6th IFOAM-Asia Scientific Conference, Yangpyung, Korea, 7-11 September.

Duangjai, S.A., Chaiyawat, P., Fukai, S., Blamey, P. (2000). Identification of nutrients limiting rice growth in soils of Northeast Thailand under water-limiting and non-limiting conditions. Plant Production Science, 3, 4,417-421.

Fazle Rabbi, S.M., Roy, R.B., Masum Miah, M., Sadiqul Amin, M. and Khandakar, T. (2014). Spatial variability of physical soil quality index of an agricultural field. Applied and Environmental Soil Science, 1 -10. 
Gałka, B., Kabała, C., Karczewska, A., Sowiński, J., (2016). Variability of soil properties in an intensively cultivated experimental field. Soil Science Annu. 67, 10-16.

Grattan, S. R. (2002). Rice is more sensitive to salinity than previously thought. California Agriculture, 56, 6,189-198.

Gulser, C., Ekberli, I., Candemir, F., Demir, Z. (2016). Spatial variability of soil physical properties in a cultivated field. Eurasian Journal of Soil Science. 5, 3,192-200.

Hazelton, PA. \& Murphy, BW. (2007). Interpreting Soil Test Results: What Do All The Numbers Mean? CSIRO Publishing: Melbourne.

Ilagan, L.A., Tabliza, R.P., Barba, R.B. Jr., Marquez, N.A. (2014). Soil fertility evaluation for rice production in Catanduanes Province, Philippines. International Journal of Scientific \& Technology Research, 3, 12, 81-87.

International Rice Research Institute (IRRI), (2015). Philippines: Department of Agriculture recognizes 2014 top rice-producing. Retrieved from http://news.irri.org/2015/04/philippines-department-ofagriculture.html

Jivraj, S.V. and Savaliya, N. V. (2004). .Organic farming: A holistic approach for safe food and sustainable agriculture. Paper presented at the Benign Environment and Safe Food, 6th IFOAM-Asia Scientific Conference, Yangpyung, Korea, 7-11 September.

Karlen, D. L., M. J. Mausbach, J. W. Doran, R. G. Cline, R. F. Harris, and Schuman, G. E.( 1997). Soil quality: A concept, definition, and framework for evaluation. Soil Science Society of America Journal, 61, 4-10.

Ketterings, Q., Reid, S., and Rao, R. (2007). Cation Exchange Capacity (CEC). Agronomy Fact Sheet Series \# 22. Department of Crop and Soil Sciences, College of Agriculture and Life Sciences, Cornell University. 
Lin-lin,S., Ming-xing,S., Chang-yin,L., Hai-hou, W., Xin-wei, Z., Mei-juan, J., Tong-dong,W. (2015). Soil phosphorus dyanamic, balance and critical $\mathrm{P}$ values in long -term fertilization experiment in Taihu Lake region. Journal of Integrative Agriculture. 1-11.

Mallarino A P \& Blackmer A M. (1992). Comparison of methods for determining critical concentrations of soil test phosphorus for corn. Agronomy Journal, 84,850-856.

McCauley, A., Jones, C. Olson-Rutz, K. (2017). Soil pH and organic matter. Nutrient Management Module No. 8. Montana State University. USA. Retrieved from http://landresources.montana.edu/nm/documents/ NM8.pdf

Oldfield, E.E, Wood, S.A., Bradford, M.A. (2017). Direct effects of sol organic matter on productivity mirror those observed with organic amendments. Plant Soil, 1-11.

Owji, A., Boroujeni, I.E., Kamali, A., Hosseinifard, S.J., Bodaghabadi, M.B. (2014). The effects of hydrometer reading times on the spatial variability of soil textures in southeast Iran. Arab Journal Geosciences, 7, 1491-1499.

Panhawar, Q.A., \& Othman, R. (2011). Effect of phosphatic fertilizer on root colonization of aerobic rice byphosphate-solubilizing bacteria. International Conference on Food Engineering and Biotechnology, 9, 145-149.

Pham, T.G.; Nguyen, H.T.; Kappas,M. ( 2018). Assessment of soil quality indicators under different agricultural land uses and topographc different agricultural land uses and topographic aspects in Central Vietnam. International Soil and Water conservation Research, 6, 4, 280-288.

Reynolds, W. D., Drury, C. F., Yang, X. M., Fox, C. A., Tan, C. S., \& Zhang, T. Q. (2007). Land management effects on the near-surface physical quality of a clay loam soil. Soil and Tillage Research Journal, 96, 1-2, 316-330. 
Sahrawat, K. L. (2005). Fertility and organic matter in submerged rice soil. Current Science, 88, 5, 735-739.

Sarwar, G., Schmeisky, H., Hussian, N., Muhammad, S., Ibrahim, M. and Safdar, E. (2008). Improvement of soil physical and chemical properties with compost application in rice-wheat cropping system. Pakistan Journal of Botany, 40, 1, 275-282.

Simpson, R.J., Oberson, A., Culvenor, R.A., Ryan, M.H., Veneklaas, E.J., Lambers, H.,Lynch, J.P., Ryan, P.R., Delhaize, E., Smith, F.A. (2011). Strategies and agronomic interventions to improve the phosphorususe efficiency of farming systems. Plant Soil, 349, 89 -120.

Surekha, K., Latha, P.C., Rao. K. V. \& Mahender Kumar, R. (2010). Grain yield, yield components, soil fertility, and biological activity under organic and conventional rice production systems. Communications in Soil Science and Plant Analysis, 41, 19, 2279-2292.

Thuithaisong, C., Parkpain, P., Shipin, O.V., Shretha, R.P., Naklang, K., DeLuane, R.D. \& Jugsujinda, A. (2011). Soil-quality indicators for predicting sustainable organic rice production. Communications in Soil science and Plant Analysis, 42, 548-568.

USDA Natural Resources Conservation Service. (2011). Soil quality indicators. Retrieved from https://www.nrcs.usda.gov/wps/portal/nrcs/ detail/soils/health/assessment/?cid=stelprdb1237387

Usowicz, B. and Lipiec, J. (2017). Spatial variability of soil properties and cereal yield in a cultivated field on sandy soil. Soil and Tillage Research, $241-250$.

Wang,Y., Zhao, X.,Guo, Z., Jia, Z., Wang, S., Ding, K. ( 2018). Response of soil microbes to a reduction in phosphorus fertilizer in rice-wheat rotation paddy soils with varying soil P levels. Soil and Tillage Research, $181,127-135$. 
Williams, J. and Goldman Smith, S. (2001). Correcting Potassium Deficiency Can Reduce Rice Stem Diseases. Better Crops, 85, 7-9. Retrieved from www.ipni.net/publication.

YosefTabar, S. (2012).Effect of nitrogen and phosphorus fertilizer on growth and yield rice (Oryza Sativa L). International Journal of Agronomy and Plant Production, 3, 12, 579-584. 